\title{
ЗАДОВОЛЕНІСТЬ ЖИТТЯМ ТА РОЛЬ ПСИХОФІЗИЧНИХ КОМПОНЕНТІВ У ЯКОСТІ ЖИТТЯ ЛЮДЕЙ ПОХИЛОГО ВІКУ
}

\begin{abstract}
Мета. Встановити співвідношення факторів, щңо впливають на задоволеність життям та роль фізичних і психологічних компонентів у якості життя людей похилого віку. Методи. У процесі дослідження використовували теоретичний аналіз та узагальнення науково-методичної літератури; педагогічні спостереження, методику визначення “Індексу життєвої задоволеності" (Live Satisfaction Index) Б. Ньюгартена (в модифікації Н. Паніної), методику “Шкала задоволеності життям” Е. Дінера, методику визначення якості життя "SF 36”, методи математичної статистики. В опитуванні брали участь 504 особи віком 60-65 років, з яких 317 жінок та 187 чоловіків (непрачюючі пенсіонери). Результати. Встановлено, щуо більшість опитуваних (69,2\% жінок та 63,7\% чоловіків) мають низький рівень задоволеності життям. Середній рівень задоволеності життям виявлено у 23,08\% респондентів жіночої статі та у 25,8\% чоловіків. Лише 7,7\% опитуваних жінок та 10,5\% чоловіків мають високий рівень індексу задоволеності життям. Більшість жінок $(75,1 \%)$ з низьким індексом вважають, що їх індекс задоволеності життям обумовлений фактором “позитивна очінка себе $і$ своӥх вчинків”, а $у$ 62,6\%) чоловіків - фактором “інтерес до життя”. Однак, такі фактори як послідовність у досягненні иілей та узгодженість між поставленими та досягнутими иілями виявилися найвагомішими серед осіб $з$ високим рівнем задоволеності життям. Згідно нашого соиіологічного опитування, у більшості осіб похилого віку спостерігається низький рівень якості життя як за фізичними, так $і$ психологічними компонентами. Висновок. У результаті проведеного дослідження встановлено, щзо більшість осіб похилого віку мають низький індекс задоволеності життям. За показниками “Шкали задоволеності життям” (SWLS) E. Дінера жінки $і$ чоловіки теж характеризуються низьким рівнем задоволеності життям. Вище середнього рівня задоволеності життям мають 11,4\% жінок та 10,2\% чоловіків, середній відповідно 5,4\% та 9,1\% і високий-3,8\% та 7,5\%. За даними соиіологічного опитування (методика SF36), у більшості жінок $і$ чоловіків похилого віку встановлено низький рівень якості життя. При ичьому, низькі показники характерні як для фізичного, так і психологічного компонентів здоров'я.
\end{abstract}

Ключові слова: похилий вік, якість життя, задоволеність життям, фізичний і психологічний компоненти.

The purpose of the study is to establish the ratio of factors influencing life satisfaction and the role of physical and psychological components in the quality of life of the elderly. Methods. In the process of research used theoretical analysis and generalization of scientific and methodological literature; pedagogical observations, the method of determining the "Live Satisfaction Index" (Live Satisfaction Index) by B. Newgarten (modified by N. Panina), the method of "Life Satisfaction Scale" by E. Diner, the method of determining the quality of life "SF 36", methods of mathematical statistics. The survey involved 504 people aged 60-65, including 317 women and 187 men (unemployed retirees). Results. It was found that the majority of respondents (69,2\% of women and 63,7\% of men) have a low level of life satisfaction. The average level of life satisfaction was found in $23.08 \%$ of female respondents and 25,\% of men. Only 7,7\% of women and 10,5\% of men surveyed have a high level of life satisfaction index. The majority of women (75.1\%) with a low index believe that their life satisfaction index is due to the factor "positive assessment of themselves and their actions", and in 62,6\%) men - the factor "interest in life". However, factors such as consistency in achieving goals and consistency between set and achieved goals proved to be the most important among people with a high level of life satisfaction. According to our opinion poll, most elderly people have a low level of quality of life in both physical and psychological components. Conclusion. The study found that most older people have a low life satisfaction index. According to E. Diner's Life Satisfaction Scale (SWLS), women and men are also characterized by a low level of life satisfaction. 11,4\% of women and 10,2\% of men have a higher average level of life satisfaction, an average of 5,4\% and 9,1\%, respectively, and a high level of 3,8\% and 7,5\%. According to a sociological survey (method SF-36), most women and older men have a low level of quality of life. At the same time, low rates are characteristic of both the physical and psychological components of health.

Keywords: old age, quality of life, life satisfaction, physical and psychological components.

Постановка проблеми й аналіз результатів останніх досліджень. Індекс задоволеності життям (Satisfaction with Life Index) був створений британським аналітичним соціопсихологом Адріаном Уайтом та засновується на даних його мета досліджен- 
ня різноманітних опитувань та індексів щодо рівня щастя громадян [13]. Вказаний індекс найсильніше корелює 3 рівнями здоров'я $(\mathrm{r}=0,62)$, багатства $(\mathrm{r}=0,52)$ та досяжності освіти $(\mathrm{r}=0,51)$ у країні. Щодо задоволеності життям у похилому віці, то вона в значній мірі залежить від фізичного здоров'я. Відомо, що якість життя, то у будь-якому віці вона відображається позитивним емоційним станом, який в свою чергу визначається фізичним, психічним, соціальним і духовним благополуччям [5].

Серед факторів, що впливають на задоволеність життям у похилому віці і успішність біосоціальної адаптації особистості виділяють: здоров'я, матеріальне становище, сімейний стан, рухову активність, взаємини з навколишнім світом і навіть спроможність керувати транспортом [2].

3'ясовано, що існують гендерні особливості відчуття задоволеності життям людьми похилого віку $[2,6,7]$. Так, у жінок це в значній мірі пов'язано зі станом здоров'я. Відтак, вони частіше ніж чоловіки відвідують лікарів, концентрують увагу на своїх недугах. Щодо чоловіків похилого віку, то для них задоволеність життям в значній мірі визначається можливістю взаємодії з навколишнім світом [9]. При цьому як для жінок, так і для чоловіків задоволеність життям визначається здатністю до найрізноманітніших форм рухової діяльності. Ряд наукових досліджень $[3,6,8,9]$, вказує на те що люди похилого віку, які ведуть активний спосіб життя є більш задоволенні власним життям, ніж ті, хто віддає перевагу пасивним формам проведення дозвілля (перегляд телепередач, перебування в соціальних мережах тощо). Але зазначимо, що задоволеність життям - це складний психофізіологічний стан, який залежить від багатьох факторів, а саме: особистої та сімейної безпеки; матеріального та сімейного благополуччя; життєвих цінностей; самореалізації; активного дозвілля; кліматичних умов; соціального статусу; соціальних контактів; соціально-політичної стабільності, впевненості у майбутньому; комфортного середовища проживання; стабільного здоров'я; рівня фізичної активності [4].

Як відомо, активне дозвілля в похилому віці є одним із найважливіших інструментів покращення якості життя $[6,10]$. Адже активне дозвілля є невід'ємною складовою життєдіяльності людини протягом всього періоду онтогенезу і забезпечує їй відновлення пластичних та енергетичних ресурсів, позитивно впливає на психоемоційну сферу [8, 11], а відтак є дієвим засобом підвищення якості життя $[2,3,8,9]$.

На думку вітчизняних та зарубіжних науковців, оздоровчо-рекреаційна рухова активність під час дозвілля є основними фактором, необхідним людям похилого віку для покращення якості життя $[8,9,11]$.

Мета дослідження - встановити співвідношення факторів, що впливають на задоволеність життям та роль фізичних і психологічних компонентів у якості життя людей похилого віку.

Методи дослідження. У процесі дослідження нами були використані такі методи: теоретичний аналіз та узагальнення науково-методичної літератури; педагогічні спостереження; методика визначення "Індексу життєвої задоволеності" ("Live Satisfaction Index" LSI) Б. Ньюгартен (в модифікації Н. Паніної), методика "Шкала задоволеності життям" (SWLS) E. Дінера; методика визначення якості життя "SF 36"; методи математичної статистики. У констатуючому експерименті брали участь 504 особи віком 60-65 років, з яких 317 жінок та 187 чоловіків. Відмічаємо, що 100\% досліджуваних, непрацюючі пенсіонери.

Результати. Встановлено, що більшість опитуваних (69,2\% жінок та 63,7\% чоловіків) мають низький рівень задоволеності життям. Це вказує на відсутність у них задоволення від повсякденного життя, наявність пасивного примирення із життєвими невдачами та сприйняття їх як належного. Водночас, вони не впевненні у собі та мають 
низьку самооцінку, незадоволені станом свого здоров'я ведуть малорухливий спосіб життя, і як результат, не отримують належної задоволеності життям. Середній рівень задоволеності життям виявлено у 23,08\% респондентів жіночої статі та у $25,8 \%$ чоловіків. Дана група досліджуваних реально оцінюють свій стан здоров'я, мають реалістичну самооцінку, адекватно оцінюють свої фізичні можливості, позитивно відносяться до повсякденної діяльності, проте не повністю відчувають задоволеність життям. При цьому, вони не проявляють ініціативу щось змінювати, покращувати свій фізичний стан, та не урізноманітнюють своє дозвілля за допомогою рухової діяльності. Лише $7,7 \%$ опитуваних жінок та 10,5\% чоловіків мають високий рівень індексу задоволеності життям.

У рамках даного опитування нами визначено питому вагу окремих факторів індексу задоволеності життям осіб похилого віку (табл. 1). Як видно 3 даної таблиці, більшість жінок $(75,1 \%)$ з низьким індексом вважають, що їх індекс задоволеності життям обумовлений фактором “позитивна оцінка себе і своїх вчинків", а у 62,6\%) чоловіків - фактором “інтерес до життя”. Однак, такі фактори як послідовність у досягненні цілей та узгодженість між поставленими та досягнутими цілями виявилися найвагомішими серед осіб з високим рівнем задоволеності життям.

Таблиия 1

Співвідношення факторів індексу задоволеності життям осіб похилого віку (за методикою Б. Ньюгартен в модифікації Н. Паніної, 2001), (n=504),\%

\begin{tabular}{|c|c|c|c|c|c|c|c|}
\hline \multirow[t]{3}{*}{ № } & \multirow{3}{*}{$\begin{array}{c}\text { Фактори індексу } \\
\text { задоволеності } \\
\text { життям }\end{array}$} & \multirow{2}{*}{\multicolumn{2}{|c|}{$\frac{\text { Високий рівень ІЗЖ }}{\text { кількість }}$}} & \multirow{2}{*}{\multicolumn{2}{|c|}{$\frac{\text { Середній рівень ІЗЖ }}{\text { кількість }}$}} & \multirow{2}{*}{\multicolumn{2}{|c|}{$\frac{\text { Низький рівень ІЗЖ }}{\text { кількість }}$}} \\
\hline & & & & & & & \\
\hline & & $\begin{array}{c}\text { чол. } \\
(\mathrm{n}=187)\end{array}$ & $\begin{array}{c}\text { жін. } \\
(\mathrm{n}=317)\end{array}$ & $\begin{array}{c}\text { чол. } \\
(\mathrm{n}=187)\end{array}$ & $\begin{array}{c}\text { жін. } \\
(\mathrm{n}=317)\end{array}$ & $\begin{array}{c}\text { чол. } \\
(\mathrm{n}=187)\end{array}$ & $\begin{array}{c}\text { жін. } \\
(\mathrm{n}=317)\end{array}$ \\
\hline 1. & Інтерес до життя & 4,3 & 4,1 & 33,2 & 28,1 & 62,6 & 67,8 \\
\hline 2. & $\begin{array}{l}\text { Послідовність у до- } \\
\text { сягненні цілей }\end{array}$ & 13,9 & 9,1 & 36,9 & 21,1 & 49,7 & 69,7 \\
\hline 3. & $\begin{array}{l}\text { Узгодженість між по- } \\
\text { ставленими та досяг- } \\
\text { неними цілями }\end{array}$ & 14,9 & 9,1 & 34,8 & 25,2 & 48,7 & 65,6 \\
\hline 4. & $\begin{array}{l}\text { Позитивна } \text { оцінка } \\
\text { себе і своїх вчинків }\end{array}$ & 9,1 & 4,7 & 42,2 & 20,2 & 53,5 & 75,1 \\
\hline 5. & $\begin{array}{l}\text { Загальний } \\
\text { настрою }\end{array}$ & 5,3 & 7,9 & 34,2 & 21,4 & 60,4 & 70,7 \\
\hline
\end{tabular}

За методикою “Шкала задоволеності життям” (SWLS) Е. Дінера (40,1\% жінок та 41,2\% чоловіків) мають низький рівень цього показника. Вони вважають, що справи у них йдуть не дуже добре, або все погано. Крім того, такий рівень незадоволеності, швидше за все, призводить до низької ефективності будь-якої діяльності, що негативно відображатиметься спочатку на емоційному стані, а згодом і на здоров'ї. До занять руховою активністю не долучаються. Такий стан пояснюємо зміною соціального статусу, відходом від активної соціальної діяльності, погіршенням матеріально-фінансвого стану і здоров'я.

Вище середнього рівня задоволеністю життям виявлено в $11,4 \%$ жінок та $10,2 \%$ чоловіків. Ця категорія осіб, як правило, має проблеми зі здоров'ям та фінансовим забезпеченням.

Середній рівень задоволеності життям констатовано у 5,4\% жінок та у 9,1\% чоловіків. Ці особи, в цілому, задоволені життям, але хотіли б поліпшити своє становище в більшості життєвих сферах, наприклад, здоров 'ї, руховій діяльності, фізичному та фінансовому станах. 
Зазначимо, що тільки у незначної частки осіб похилого віку (3,8\% жінок та 7,5\% чоловіків) виявлено високий рівень задоволеності життям. Звичайно, і у них є негаразди, яких вони хотіли б позбутися, але в цілому вони насолоджуються життям і відчувають, що в основних сферах їх життя - сім'я, фінанси, дозвілля, рухова діяльність, здоров'я - все більш-менш добре.

Отже, на підставі результатів соціологічного дослідження можна стверджувати, що люди похилого віку мають переважно низький та середній рівень задоволеності життям.

Як відомо, якість життя залежить від ряду факторів (табл. 2), а саме: фізичного, функціонального, психоемоційного та соціального станів [13]. У зв'язку із цим ця категорія людського життя формується у відповідності із біологічними, психологічними та соціальними рівнями структури особистості людини.

Критерії ефективності якості життя, рекомендовані ВООЗ [13]

Таблиия 2

\begin{tabular}{|l|l|}
\hline Фізичні & Сила, енергія, втома, біль, дискомфорт, сон, відпочинок \\
\hline $\begin{array}{l}\text { Рівень } \\
\text { незалежності }\end{array}$ & $\begin{array}{l}\text { Повсякденне активність, працездатність, залежність від ліків і } \\
\text { лікування }\end{array}$ \\
\hline Психологічні & $\begin{array}{l}\text { Позитивні емоції, мислення, вивчення, запам'ятовування, кон- } \\
\text { центрація, самоцінка, зовнішній вигляд, негативні переживання }\end{array}$ \\
\hline $\begin{array}{l}\text { Життя в } \\
\text { суспільстві }\end{array}$ & Особисті взаємини, суспільна цінність суб’єкта, сексуальна активність \\
\hline $\begin{array}{l}\text { Навколишнє } \\
\text { середовище }\end{array}$ & $\begin{array}{l}\text { Благополуччя, безпека, побут, забезпеченість, доступність і якість ме- } \\
\text { дичного і соціального забезпечення, доступність інформації, можли- } \\
\text { вість навчання та підвищення кваліфікації, дозвілля, екологія (забруд- } \\
\text { нювачі, шум, населеність, клімат) }\end{array}$ \\
\hline Духовність & Релігія, особисті переконання \\
\hline
\end{tabular}

Згідно нашого соціологічного опитування, у більшості осіб похилого віку спостерігається низький рівень якості життя за всіма компонентами (табл. 3).

Таблиия 3

Фізичні та психологічні показники якості життя осіб похилого віку (n=504), бали

\begin{tabular}{|c|c|c|c|}
\hline $\begin{array}{l}\text { Компоненти якості життя } \\
\text { (SF 36) }\end{array}$ & Шкала & чол $(\mathrm{n}=187)$ & жін $(\mathrm{n}=317)$ \\
\hline \multirow{4}{*}{$\begin{array}{l}\text { Фізичний компонент } \\
\text { здоров'я: }\end{array}$} & Фізична активність & 74,7 & 62,1 \\
\hline & $\begin{array}{l}\text { Роль фізичних проблем у об- } \\
\text { меженні життєдіяльності }\end{array}$ & 63,4 & 57,2 \\
\hline & Рівень болю & 70,2 & 74,1 \\
\hline & Загальний стан здоров’я & 66,3 & 65,3 \\
\hline \multirow{4}{*}{$\begin{array}{l}\text { Психологічний компонент } \\
\text { здоров'я: }\end{array}$} & Життєздатність & 65,3 & 60,7 \\
\hline & Соціальна активність & 60,7 & 66,4 \\
\hline & $\begin{array}{l}\text { Роль емоційних проблем у об- } \\
\text { меженні життєздатності }\end{array}$ & 61,9 & 71,9 \\
\hline & Психічне здоров’я & 73,4 & 71,6 \\
\hline
\end{tabular}

Найнижчі показники характерні для психологічного компоненту здоров'я у чоловіків, а саме: соціальна активність (60,7 бали) та емоційна складова життєздатності (61,9 бали).

Очевидно, це обумовлено зменшенням соціальної активності (переходом у соціальну групу “пенсіонер”) i, як наслідок, погіршенням фізичного та емоційного стану. 
Доволі низькими виявилися показники у жінок: роль фізичних проблем у обмеженні життєдіяльності (57,2 бали) та життєздатність (60,7 бали). Це вказує на те, що щоденна життєдіяльність жінок значно обмежена їх фізичним здоров'ям.

Дискусія. Отож, результати нашого дослідження знайшли своє підтвердження у дослідженнях Бороздиної Л.В., Молчанової О.Н. (2003), Герасимової Н.В. (2003), Мицкан Б., Мицкан Т. (2020), White А. (2007). Дані автори зазначають, що задоволеність життям та психофізичні компоненти якості життя людей похилого віку мають схильність до зниження в порівнянні з більш ранніми етапами онтогенезу. Разом з тим науковці вказують, що оцінюючи задоволеність життя та іï фактори, серед осіб похилого віку можна виокремити дві зони локалізації: середню і низьку [2]. Водночас, виявлено, що середній рівень задоволеності життям у 23,08\% жінок та у 25,8\% чоловіків. Рівень задоволеності життям, на думку Павлової Ю. [6], мають прямолінійний в'язок із якістю життя осіб різного віку, а в похилому віці дає можливість визначити загальну пристосованість до старості. Факторами, які впливають на якість життя, за даними Мицкана Б., Мицкан Т. [5] є: спадковість, харчування, якість довкілля (атмосфери, гідросфери, літосфери), рухова активність, адекватність вибору професійної діяльності, рівень стресостійкості і комунікабельності, фізичного, емоційного, психічного і сексуального здоров'я, сімейний стан, безпека, і особливо біобезпека, медичне обслуговування, матеріально-фінансове забезпечення.

\section{Висновки.}

1. У результаті проведеного дослідження встановлено, що більшість осіб похилого віку (69,2\% жінок та 63,7\% чоловіків) мають низький індекс задоволеності життям. За показниками “Шкали задоволеності життям" (SWLS) Е. Дінера (40,1\% жінок та 41,2\% чоловіків) теж характеризуються низьким рівнем задоволеності життям.

Вище середнього рівня задоволеність життям мають $11,4 \%$ жінок та $10,2 \%$ чоловіків, середній - 5,4\% жінок та 9,1\% чоловіків, високий - 3,8\% жінок та 7,5\% чоловіків.

2. Згідно соціологічного опитування за методикою SF-36, у більшості жінок і чоловіків похилого віку спостерігається низький рівень якості життя. При цьому, низькі показники характерні як для фізичного, так і психологічного компонентів здоров'я.

Перспективи дослідження даної проблеми полягають в розробці та впровадженні технології організації здорового старіння з використанням потенціалу оздоровчо-рекреаційної діяльності, що спрямовані на покращення задоволеності життям та його якості у осіб похилого віку.

1. Бороздина ЛВ, Молчанова ОН. Особенности самооценки в позднем возрасте. В кн.: Краснова ОВ, Лидерс АГ. Психология старости и старения. М.: Издательский центр “Академия”; 2003: 135-149.

2. Вихованець ЮГ. Показники біологічного та психологічного віку в діагностиці функціональних станів людини. Університетська клініка. 2012; 1 (8): 39-42.

3. Гакман Анна. Вплив університетів третього віку на психофізичну активність осіб старшого покоління. Вісник Прикарпатського університету. Фізична культура. 2019; 34: 39-45.

4. Герасимова НВ. Социальная адаптация пожилых людей в современной ситуации: автореф. дис. соціол. наук. Саранск, 2001. 12 с.

5. Мицкан Б, Мицкан Т. Якість життя людини: біосоціальний вимір. Фізична активність і якість життя людини: збірник тез доповідей IV Міжнародної науково-практичної Інтернет-конференції. Луцьк, 2020: 3 .

6. Павлова Ю.О. Структура якості життя населення . Слобожанський науково-спортивний вісник. 2015; 5 (49): 90-4.

7. Приходько ВВ, Томенко ОА, Михайличенко ОВ. Удосконалення організації та змісту наукових досліджень 3 фізичної культури і спорту як важлива передумова їх реформування. Педагогічні науки: теорія, історія, інноваційні технології. Суми: Вид-во СумДПУ імені А.С. Макаренка, 2016; 3(57): 419-429. 
8. Томенко О, Горюк П, Слобожанінов А. Особливості рекреаційно-оздоровчої діяльності у структурі дозвілля осіб похилого віку. Вісник Кам'янець-Подільського національного університету імені Івана Огієнка. Фізичне виховання, спорт і здоров'я людини. 2020; 17: 80-84.

9. Футорний СМ. Вплив занять оздоровчо-рекреаційної рухової активності на функціональний стан жінок похилого віку в оздоровчих групах. Вісник Прикарпатського університету імені Василя Стефаника. Фізична культура. 2019; 34: 26-32.

10. Andrieieva O, Hakman A, Kashuba V, Vasylenko M, Patsaliuk K, Koshura A, and oth. Effects of physical activity on aging processes in elderly persons. Journal of Physical Education and Sport. 2019; 4: 13081314. DOI:10.7752/jpes.2019.s4190.

11. Hakman A, Andrieieva O, Kashuba V, Omelchenko T, Carp I, Danylchenko Vl, Levinskaia Ks. Technology of planning and management of leisure activities for working elderly people with a low level of physical activity. Journal of Physical Education and Sport. 2019; 6.

12. WHO-World health organization. Active ageing. A policy framework. Available at https://apps.who.int/iris/bitstream/handle/10665/67215/WHO_NMH_NPH_02.8.pdf;jsessionid=8D06C9 9313B2750536365249EE07602F?sequence $=1$.

13. White A. A Global Projection of Subjective Well-being: A Challenge To Positive Psychology? Psychtalk. 2007; 56: 17-20.

\section{References}

1. Borozdyna LV, Molchanova ON. Osobennosty samootsenky v pozdnem vozraste . V kn.: Krasnova OV, Lyders AH. Psykholohyia starosty y starenyia. M.: Yzdatelskyi tsentr “Akademyia”; 2003: 135-149.

2. Vykhovanets YuH. Pokaznyky biolohichnoho ta psykholohichnoho viku v diahnostytsi funktsionalnykh staniv liudyny . Universytetska klinika. 2012; 1 (8): 39-42.

3. Hakman Anna. Vplyv universytetiv tretoho viku na psykhofizychnu aktyvnist osib starshoho pokolinnia. Visnyk Prykarpatskoho universytetu. Fizychna kultura. 2019; 34: 39-45.

4. Herasymova NV. Sotsyalnaia adaptatsyia pozhylukh liudei v sovremennoi sytuatsyy: avtoref. dys. sotsiol. nauk. Saransk, 2001. $12 \mathrm{~s}$.

5. Mytskan B, Mytskan T. Yakist zhyttia liudyny: biosotsialnyi vymir. Fizychna aktyvnist i yakist zhyttia liudyny: zbirnyk tez dopovidei IV Mizhnarodnoi naukovo-praktychnoi Internet-konferentsii. Lutsk, 2020. S. 3.

6. Pavlova YuO. Struktura yakosti zhyttia naselennia . Slobozhanskyi naukovo-sportyvnyi visnyk. 2015; 5(49): 90-94.

7. Prykhodko VV, Tomenko OA, Mykhailychenko OV. Udoskonalennia orhanizatsii ta zmistu naukovykh doslidzhen z fizychnoi kultury i sportu yak vazhlyva peredumova yikh reformuvannia. V zb.: Sbruieva AA. (holov. red). Pedahohichni nauky: teoriia, istoriia, innovatsiini tekhnolohii. Sumy: Vyd-vo SumDPU imeni A.S. Makarenka; 2016; 3(57): 419-429.

8. Tomenko O, Horiuk P, Slobozhaninov A. Osoblyvosti rekreatsiino-ozdorovchoi diialnosti u strukturi dozvillia osib pokhyloho viku. Visnyk Kamianets-Podilskoho natsionalnoho universytetu imeni Ivana Ohiienka. Fizychne vykhovannia, sport i zdorovia liudyny. 2020; 17: 80-84.

9. Futornyi SM. Vplyv zaniat ozdorovcho-rekreatsiinoi rukhovoi aktyvnosti na funktsionalnyi stan zhinok pokhyloho viku v ozdorovchykh hrupakh. Visnyk Prykarpatskoho universytetu imeni Vasylia Stefanyka. Fizychna kultura. 2019; 34: 26-32.

10. Andrieieva O, Hakman A, Kashuba V, Vasylenko M, Patsaliuk K, Koshura A, and oth. Effects of physical activity on aging processes in elderly persons. Journal of Physical Education and Sport. 2019; 2019 (4): 1308-1314. DOI:10.7752/jpes.2019.s4190.

11. Hakman A, Andrieieva O, Kashuba V, Omelchenko T, Carp I, Danylchenko Vl, Levinskaia Ks. Technology of planning and management of leisure activities for working elderly people with a low level of physical activity. Journal of Physical Education and Sport. 2019; 6.

12. WHO-World health organization. Active ageing. A policy framework. Available at https://apps.who.int/ iris/bitstream/handle/10665/67215/WHO_NMH_NPH_02.8.pdf;jsessionid=8D06C99313B2750536365249 EE07602F?sequence $=1$.

13. White A. A Global Projection of Subjective Well-being: A Challenge To Positive Psychology? Psychtalk. 2007; 56: 17-20.

\footnotetext{
Цитування на цю статтю:

Гакман АВ, Дудіцька СП, Вілігорський ОМ. Задоволеність життям та роль психофізичних компонентів у якості життя людей похилого віку Вісник Прикарпатського університету. Серія: Фізична культура. 2020 Листоп 24; 36: 3-9
} 


\begin{tabular}{|c|c|}
\hline Відомості про автора: & Information about the author: \\
\hline $\begin{array}{l}\text { Гакман Анна Вікторівна - кандидат наук з фізич- } \\
\text { ного виховання і спорту, доцент кафедри теорії та } \\
\text { методики фізичного виховання і спорту, Чернівець- } \\
\text { кий національний університет імені Юрія Федь- } \\
\text { ковича (Чернівці, Україна) }\end{array}$ & $\begin{array}{l}\text { Hakman Anna Viktorivna - Candidate of Scien- } \\
\text { ce (Physical Education and Sport), Associate Pro- } \\
\text { fessor of Theory and Methods of Physical Educa- } \\
\text { tion and Sports, Yuriy Fedkovych Chernivtsi } \\
\text { National University (Chernivtsi, Ukraine) }\end{array}$ \\
\hline \multicolumn{2}{|l|}{$\begin{array}{l}\text { e-mail: an.hakman@chnu.edu.ua } \\
\text { https://orcid.org/0000-0002-7485-0062 }\end{array}$} \\
\hline $\begin{array}{l}\text { Дудіцька Світлана Петрівна - викладач кафедри } \\
\text { теорії та методики фізичного виховання і спорту, } \\
\text { Чернівецький національний університет імені Юрія } \\
\text { Федьковича (Чернівці, Україна) }\end{array}$ & $\begin{array}{l}\text { Dudits'ka Svitlana Petrivna - lecturer at the } \\
\text { Department of Theory and Methods of Physical } \\
\text { Education and Sports, Yuriy Fedkovych Cher- } \\
\text { nivtsi National University (Chernivtsi, Ukraine) }\end{array}$ \\
\hline \multicolumn{2}{|l|}{$\begin{array}{l}\text { e-mail: s.duditska@chnu.edu.ua } \\
\text { https://orcid.org/0000-0001-5015-2465 }\end{array}$} \\
\hline $\begin{array}{l}\text { Вілігорський Олександр Миколайович - старший } \\
\text { викладач кафедри фізичної культури та основ } \\
\text { здоров'я, Чернівецький національний університет } \\
\text { імені Юрія Федьковича (Чернівці, Україна) }\end{array}$ & $\begin{array}{l}\text { Vilihors'kyy Oleksandr Mykolayovych - Senior } \\
\text { Lecturer of the Department of Physical Culture } \\
\text { and Fundamentals of Health, Yuriy Fedkovych } \\
\text { Chernivtsi National University (Chernivtsi, } \\
\text { Ukraine) }\end{array}$ \\
\hline
\end{tabular}

УДК 796: 771.214

doi: 10.15330/fcult.36.9-16

Вімалій Кашуба, Сергій Холодов

\section{БІОМЕХАНІЧНІ АСПЕКТИ ХОДЬБИ ДІТЕЙ МОЛОДШОГО ШКІЛЬНОГО ВІКУ}

Мета. Визначити особливості часової структури ходьби практично здорових дітей 6-8 років. Методи. Для виконання поставлених завдань використано такі методи дослідження, як аналіз науковометодичної літератури та документальних матеріалів, відеометрія, пакет прикладної програми “БіоВідео”. Результати. Ходьба є ичилічним локомоторним рухом, здійснюваним за способом відштовхування. Характерною особливістю ходьби є наявність постійного контакту опорної ноги (період одиночної опори) або обох ніг (період подвійної опори). Саме ходьба може служити в якості критерію оцінки стану моторики людини. У той же час, накопичені більш ніж за столітній період дані, щзо стосуються питань фазового складу ходьби, ролі і иільової спрямованості кожної з фаз в ичилі подвійного кроку, механізму реалізації основних рухових дій, принципово один від одного не відрізняються. При цьому інформація про формування біомеханіки ходьби у молодших школярів обмежена. Проведені дослідження свідчать про те, щуо тривалість фази подвійної опори при лівій опорній нозі у практично здорових хлопчів 6 років дорівнюе в середньому $0,12 c(S=0,01 c), y$ дівчат $-0,14 c(S=0,01 c)$, водночас $y$ практично здорових хлопиів і дівчат 7 років показники тривалості иієї фази однакові і складають 0,14 $\mathrm{c}$ $(S=0,01$ c), так само однакова тривалість иүієї фази у хлопців і дівчат 8 років і становить $0,16 c(S=0,02$ с y хлопців $i S=0,01$ с у дівчат). Необхідно відмітити, щуо статистично значущеї різниці у показнику тривалості фази подвійної опори при лівій опорній нозі між хлопиями та дівчатами у кожній з вікових категорій 7-8 років не спостерігалоя (р > 0,05) на відміну від хлопців і дівчат 6 років, у яких показники тривалості иієї фази статистично значуще відрізнялися ( $p<0,05)$, щуо підтверджено за допомогою критерію Стьюдента для незалежних вибірок. Варто відмітити, щуо у заключній фазі подвійного кроку ходьби, зафіксовано статистично значуще збільшення ї тривалості у дівчат 7 років, порівняно з хлопиями иъього віку на 0,04 c (p < 0,05), ї̈ тривалість становить у дівчат 7 років, а також у хлопиів і дівчат 8 років в середньому 0,24 с $(S=0,03$ с у дівчат 7 років і хлопців 8 років $i \mathrm{~S}=0,02$ с у дівчат 8 років). Висновок. В результаті проведеного дослідження була вивчена структура циику ходьби практично здорових дітей 6-8 років, значимість яких підтверджена об'єктивними часовими показниками. Підтверджено думку ряду фахівиів, які вказують, щъо біомеханічна структура локомоторного акту практично повністю складається у віиі 7-8 років.

Ключові слова: діти молодшого шкільного віку, статодинамічна постава, часова структура ходьби, біомеханічні аспекти. 